\title{
LEADERSHIP DISPATCHES
}




\section{HIGH RELIABILITY AND CRISIS MANAGEMENT}

Series Editors: Karlene H. Roberts and Ian I. Mitroff

\section{Series Titles}

The Social Roots of Risk: Producing Disasters, Promoting Resilience

By Kathleen Tierney

2014

Learning from the Global Financial Crisis: Creatively, Reliably, and Sustainably Edited by Paul Shrivastava and Matt Statler

2012

Swans, Swine, and Swindlers: Coping with the Growing Threat of Mega-Crises and Mega-Messes

By Can M. Alpaslan and Ian I. Mitroff

2011

Dirty Rotten Strategies: How We Trick Ourselves and Others into Solving the Wrong Problems Precisely

By Ian I. Mitroff and Abraham Silvers

2010

High Reliability Management: Operating on the Edge

By Emery Roe and Paul R. Schulman 2008 


\title{
LEADERSHIP

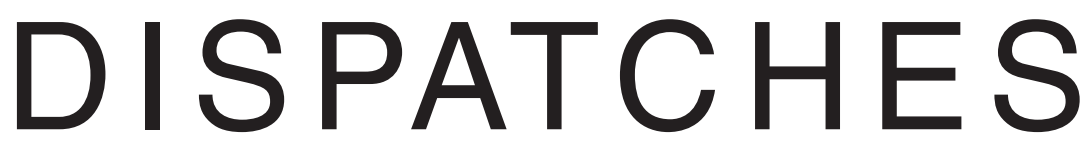

CHILE'S EXTRAORDINARY COMEBACK FROM DISASTER

\author{
Michael Useem \\ Howard Kunreuther \\ Erwann Michel-Kerjan
}

STANFORD BUSINESS BOOKS

An Imprint of Stanford University Press

Stanford, California 


\section{Stanford University Press Stanford, California}

(O2015 by the Board of Trustees of the Leland Stanford Junior University. All rights reserved

No part of this book may be reproduced or transmitted in any form or by any means, electronic or mechanical, including photocopying and recording, or in any information storage or retrieval system without the prior written permission of Stanford University Press.

Library of Congress Cataloging-in-Publication Data

Useem, Michael, author.

Leadership dispatches : Chile's extraordinary comeback from disaster / Michael Useem, Howard Kunreuther, and Erwann Michel-Kerjan. pages $\mathrm{cm}-$ (High reliability and crisis management)

Includes bibliographical references and index.

ISBN 978-0-8047-9387-2 (cloth : alk. paper)

1. Chile Earthquake, Chile, 2010 (February 27) 2. Earthquake relief-Chile. 3. Emergency management-Chile. 4. LeadershipChile. 5. Chile-Economic conditions-21st century. 6. ChilePolitics and government-21st century. I. Kunreuther, Howard, author. II. Michel-Kerjan, Erwann, author. III. Title. IV. Series: High reliability and crisis management.

HV600 2010.C5 U57 2015

363.34 ' $9580983-\mathrm{dc} 23$

2014034995

ISBN 978-0-8047-9449-7 (electronic)

Printed in the United States of America on acid-free, archivalquality paper

Typeset at Stanford University Press in Helvetica and 10.5/15 Minion

Special discounts for bulk quantities of Stanford Business Books are available to corporations, professional associations, and other organizations. For details and discount information, contact the special sales department of Stanford University Press. Tel: (650) 736-1782, Fax: (650) 736-1784 